\title{
User perceptions of urine diversion dehydration toilets: Experiences from a cross-sectional study in eThekwini Municipality
}

\author{
E Roma ${ }^{1,2 *}$, K Philp², C Buckley ${ }^{2}$, S Xulu³ and D Scott ${ }^{4}$ \\ 'Environmental Health Group, London School of Hygiene and Tropical Medicine, London, UK \\ ${ }^{2}$ Pollution Research Group, University of KwaZulu-Natal, Durban, South Africa \\ ${ }^{3}$ Water and Sanitation Unit, eThekwini Municipality, Prior Road, Durban, South Africa \\ ${ }^{4}$ School of Development Studies, University of KwaZulu-Natal, Durban, South Africa
}

\begin{abstract}
The current environmental challenges that most middle- and low-income countries have been experiencing has led to new environmentally sustainable and economically viable sanitation solutions, such as waterless systems with source separation of human waste. We conducted a cross-sectional study in eThekwini municipality to explore the post-implementation challenges of urine diversion dehydration toilets (UDDTs) after a decade of installation and the adaptive processes necessary to increase the sustained use of the toilets. A structured questionnaire was administered to 17499 households in 65 rural and per-urban areas of eThekwini using mobile phone technology. Results report low levels of satisfaction with the facilities as well as an association between perceived smell in the toilets and malfunctioning of the pedestal, and low use of UDDTs when a pit latrine is present in the dwelling perimeter. Conclusions relate to the importance of educational and promotional activities that stress the economic return derived from reusing urine and excreta in agricultural activities.
\end{abstract}

Keywords: Sanitation, urine diversion toilets, user satisfaction, South Africa

\section{INTRODUCTION}

Over recent years concerns have been raised within the global scientific community about the environmental challenges and shortfalls that our planet is experiencing. The Rio de Janeiro Earth Summit of 1992 first introduced to the policy agenda the alarming issues of climatic change, environmental degradation and natural resource scarcity (Langergraber and Muellegger, 2005; Redclift, 2005). The global environmental crisis has aggravated, among others, the distribution and availability of water, in particular in low- and middle-income countries. Approximately 1.2 billion people live in areas characterised by water scarcity and a further 1.6 billion live in conditions of water stress, with subsequent impacts on the achievement of environmental sustainability and eradication of extreme hunger (UN-Water, 2006). Population growth and rapid urbanisation further exacerbate this trend by undermining governments' ability to provide basic services and ensure food security (Austin and Van Vuuren, 2001). The impacts of inadequate water and lack of sanitation on human lives translate into environmental and health challenges which further fuel the vicious circle of poverty (Langergraber and Muellegger, 2005).

South Africa, with other Sub-Saharan countries, is classified as a water-stressed country, with a yearly per capita availability of between 1100 and $1700 \mathrm{~m}^{3}$ of freshwater (UNEP, 1999). Scientists have estimated that by 2050 South Africa will experience a progressive decrease of (economically usable) freshwater resources, which will force the country to develop adaptive mechanisms for water conservation and wastewater management (Austin and Van Vuuren, 2004). With the

\footnotetext{
To whom all correspondence should be addressed

苗 +44 (0) 207927 2133; e-mail: elisa.roma@lshtm.ac.uk

Received 4 June 2012; accepted in revised form 20 March 2013
}

realisation that conventional centralised wastewater treatments, using drinking water to flush toilets, are environmentally unsustainable and present financial and environmental costs for governments (Esrey, 2000), alternative waste management options are to be sought. These are based on a novel characterisation of environmental pollution, moving from disposal of sewage to the reuse of urine and faeces, and are based on a re-conceptualisation of sanitation, from the 'dropflush-forget' model to protection of the environment at source (Drangert, 1998; Austin and Van Vuuren, 2004) by means of 'drop and reuse' models. It is estimated that each year an average adult produces $500 \ell$ of urine and $50 \ell$ of faeces, from which sources of nutrients, in particular, nitrogen $(\mathrm{N})$, potassium $(\mathrm{K})$ and phosphorus $(\mathrm{P})$, can be recovered in quantities which are approximately equal to the amount of food ingested (Drangert, 1998).

Ecological economists argue that growth which uses natural resource capital and throws this away as waste is no longer sustainable, and has reached its optimal scale. The ecologist's credo, by which economies can develop without growing, implies a revolutionary change in people's mindsets and perceptions towards their waste (Daly and Farley, 2004). In an era where we are encouraged to think about reusing our waste, through recycling of material and recovering of nutrients, it is essential to understand the socio-technical implications for new forms of waste management.

This contribution presents and discusses results from one of the biggest cross-sectional post-implementation studies of urine diversion dehydration toilets (UDDTs) in Southern Africa. The assessment of users' acceptance of the service and the status of the toilets themselves is extremely important in view of the recent involvement of eThekwini Municipality in the research and development of new waste management practices, such as the collection of urine for struvite production and the reuse of nutrients in agriculture. 


\section{Dry sanitation: the eThekwini Model}

South Africa's water and sanitation backlog is undoubtedly related to its historical development and the neglect of formerly Black urban and rural areas since the colonial and Apartheid eras (Chaplin, 2004; Penner, 2010). The end of Apartheid marked the transition from the supply of water and sanitation based on racial lines (with White South Africans being privileged over the remaining population), to the establishment of water and sanitation access as a principle of human dignity, to which every South African has a right.

The implementation of dry sanitation in eThekwini municipality can be traced back to the beginning of 2001, when the municipal boundaries expanded from 1366 to 2297 $\mathrm{km}^{2}$, encapsulating a total population of 3.5 million. The newly-included parts of eThekwini Metro were rural or peri-urban areas comprising approximately 75000 houses, $80 \%$ of which had no appropriate water or sanitation facilities (Gounden et al., 2006). Exacerbating the uneven distribution] of resources is the high degree of migration which affects both urban and peri-urban areas of eThekwini municipality. These range from 'deep rural' areas; to peri-urban areas to dense informal settlements adjacent to formal, relatively more central areas of the city (Roma et al., 2011). The urgency to provide adequate sanitation to the new areas was further fuelled by a cholera epidemic which occurred in the province of KwaZulu-Natal from August 2000 to July 2001, with 105389 registered cases and 219 documented deaths (Mudzanani et al., 2003). This incident and the consequences for the population's health focused the Government's attention on the need to -address the water and sanitation backlog as a matter of urgency, through the implementation of an integrated water and sanitation project followed by hygiene education and training (Roma et al., 2010). South African legislation (DWAF, 2001) set the ambitious goal to provide access to all South Africans to at least basic sanitation facilities by 2014 , under the slogan 'sanitation is dignity' (Eales, 2008). In adapting national regulations, several municipalities, and, in the first instance, eThekwini, identified UDDTs as the minimum standard for sanitation (DWAF, 2003). This political vision however hardly matches the aspirations of poor South Africans, who, after the service discrimination during Apartheid, aspire to achieve the same infrastructural services offered to the White population, which in this instance is in-house flushed toilets and piped water (Eales, 2008).

In addressing national legislation, eThekwini Municipality has embarked on a project which aims to provide a urine diversion dehydration toilet (UDDT) and a yard tank, filled free of charge with $9 \mathrm{kl}$ of water per month (EWS, 2010), to all households in un-served rural and peri-urban areas of eThekwini Municipality. At the time this cross-sectional study was conducted, official statistics revealed that an estimated 74606 households in 65 areas had UDDTs installed (Fig. 1).

The eThekwini model of dry sanitation is a waterless system which features a double-vault dry ventilated toilet based on separation of urine from faeces. The collected urine is diverted to a soak away which penetrates the soil, and a plastic pedestal is located above the first chamber, which collects faeces, anal cleansing material and bulking agents. Once the first vault is full, the pedestal is moved over to the second vault. Once the latter is full, the content of the first vault, which has undergone pathogen deactivation, is manually emptied and buried. Typically, one vault takes between 6 to 12 months to fill, depending on household size and diet type. 
At the current stage, the eThekwini model of dry sanitation does not involve the reuse of human urine and excreta. Several risk assessments on the reuse of faecal material from UDDTs have been conducted, with unfavourable results in terms of excreta re-use. Trönnberg et al. (2010), for instance, screened samples from the faecal vaults of 120 UDDTs in eThekwini and found a high occurrence of both protozoan and helminth infections: Ascaris lumbricoides (59\%), Giardia intestinalis (54\%), Trichuris trichiura (48\%), Cryptosporydium spp. (21\%) and Taenia spp. (18\%). The high pathogen load recorded in these areas suggests the need for further community health and hygiene education as a prerequisite for human waste reuse which complies with WHO guidelines for sludge reuse in agriculture (WHO, 2006).

This cross-sectional study was commissioned by eThekwini Municipality to explore the current status of use of UDDTs and problems associated with use. The information gathered during the study was deemed necessary to inform future waste recycling policies at municipal and national level. This study sought to answer the following research questions:

- What are the post-implementation issues emerging from monitoring of UDDTs in eThekwini Municipality?

- What are the adaptive processes which take place in ensuring sustainability of dry sanitation in eThekwini Municipality?

\section{METHODOLOGY}

To respond to the above-described research questions a crosssectional study was designed, which employed a structured questionnaire administered to 17449 householders in 65 areas of eThekwini Municipality. The purpose of the survey was to evaluate the use and conditions of UDDTs, whilst also answering questions related to the social acceptability of the systems. The survey, conducted between January and May 2011, used mobile phone technology (Mobenzi Researcher, formerly Mobile Researcher) to collect, collate and analyse the data. A pilot test of data collection and the elicitation instrument was conducted between December 2010 and January 2011. Considering the magnitude of the sample size, mobile phones were a more cost-effective method, which allowed for better quality control of the data (monitoring fieldworkers in real time) and lower storage costs than pen and paper surveys. Furthermore, the use of mobile phones proved to be relatively quick compared to conventional methods.

This study employed a structured, closed-ended questionnaire to collect data on use, benefits and maintenance of the UDDTs in all implementation areas. The research instrument consisted of 14 questions exploring patterns of use and the perceived benefits of UDDTs, as well as an observation checklist that was compiled by trained enumerators. The questionnaire was translated into IsiZulu, programmed in JavaScript and loaded onto the mobile phones. To elicit experiences of UDDT technologies, users were randomly selected during transect walks in the communities. Random selection promoted reliability, preventing the emergence of bias in selecting respondents. The required sample size per settlement was calculated using the following formula, based on the total population size, sampling error, and a confidence level of 95\% (Israel, 1992).

$$
n=\left(N /\left(1+N^{*} e^{\wedge} 2\right)\right.
$$

where:

$$
\begin{array}{ll}
n & =\text { sample size } \\
N & =\text { total population } \\
e & =\text { sampling error }
\end{array}
$$

Through this formula an appropriate sample size was calculated for each intervention area. Enumerators were selected among educated local people, and, depending on the area's dimensions, an appropriately sized team was identified. Enumerators were trained on the research instrument, data collection through the use of mobile phones, as well as on respondent selection. As house numbers were not always available to pre-select the sample frame, enumerators were instructed to choose every $7^{\text {th }}$ house in the area until the desired sample frame was reached. The use of mobile phones for administering the survey enabled the researcher to track progress in data collection, as well as to assess enumerators' performances.

\section{RESULTS}

The aggregate results for the 17448 households investigated are reported here. The household characterisation is reported in Table 1.

\begin{tabular}{|l|l|}
\hline \multicolumn{2}{|c|}{ TABLE 1 } \\
Household characteristics \\
\hline Household size \\
\hline Min & 1 \\
\hline Max & 30 \\
\hline Mean & 6.80 \\
\hline
\end{tabular}

Monitoring and evaluation conducted by municipal environmental health officers in the areas of implementation reported that several households had UDDTs converted into flush toilets. To identify this practice and thus explore patterns of use for UDDTs, questions related to the presence of other sanitation systems or the conversion of UDDTs were asked. Of the total sample of respondents, $8.4 \%$ (1 465) reported having converted their UDDT into a flush system and were therefore not further considered in the survey (Table 2).

\begin{tabular}{|c|c|c|c|c|}
\hline \multicolumn{5}{|c|}{ TABLE 2 } \\
Households that converted UDDTs into flush toilets
\end{tabular}

As discussed in the introduction, conventional flush toilets are considered as the standard to which poor African people should aspire (Eales, 2008). Whether some areas with converted UDDTs (such as Zwelisha and KwaNgcolosi) are located in close proximity to the central parts of eThekwini connected to the sewer line was not established, and there is insufficient evidence to either prove or disprove the hypothesised presence of a spatial pattern in toilet acceptance and usage, based on assumptions reported from municipal environmental health workers.

Furthermore, a considerable percentage of households 14\% (2 243) reported having an unimproved pit latrine in close proximity to the dwelling, and $84 \%$ of these pit latrines were reported to still be in use. The use of an alternative sanitation facility may be dictated by several reasons, such as the closer proximity of the pit latrine to dwellings, personal habits and perceptions of what represents a dignified sanitation system. 
A high proportion of UDDT users was identified, with $80 \%$ ( $n=12760$ ) of households reporting always using the toilet and only $13 \%$ ( $n=2074)$ using the toilets some of the time. Areas such as Cliffdale (88\%), Masuku (89\%), Mnamatha (90\%) and Ngomweni (100\%) have the highest proportion of households using the UDDT most of the time. Only 7\% ( $n=1117)$ of the households interviewed reported never using their UDDTs; these were located among the areas of Gundintaba, Ngonoma, Wood Glen Rural, Mahlabathini, Msunduzi, Bux Farm and Denge.

Of the valid sample of 15983 households, 85\% ( $n=13582)$ of households reported that all members use the UDDT; in $8 \%(n=1302)$ of dwellings only some family members use the UDDT and in $6.5 \%(n=1029)$ of households nobody uses the UDDT. Further investigation is needed to categorise which household members do not use UDDTs and whether trends can be identified across age and gender. Areas such as Eshekelekhleni (14\%), Wood Glen Rural (13\%), Bux Farm (10\%), Msunduzi (10\%) and eSthumba (10\%) had the highest proportion of households that had never used their UDD toilets. Conversely, areas like Thafeni, Mhali and Umzinyathi had the smallest proportion of households whose members had never used the toilets $(0-1 \%)$. Respondents were asked to explore if male household members used the urinals in the UDTTs. Urinals are used by $51 \%(n=8101)$ of male respondents.

The majority of sampled households (90\%) reported having received education on the use and maintenance of UDDTs (Table 3).

\begin{tabular}{|l|c|c|}
\hline \multicolumn{3}{|c|}{ TABLE 3 } \\
Respondents who received information about \\
UDDT use and maintenance \\
\hline Responses & $\begin{array}{c}\text { Frequency } \\
(\boldsymbol{n})\end{array}$ & $\begin{array}{c}\text { Percentages } \\
(\%)\end{array}$ \\
\hline $\begin{array}{l}\text { Respondents who reported having } \\
\text { been informed about UDDTs use } \\
\text { and maintenance }\end{array}$ & 14319 & 90 \\
\hline $\begin{array}{l}\text { Respondents who reported not to } \\
\text { have been informed about UDDTs } \\
\text { use and maintenance }\end{array}$ & 1073 & 6.7 \\
\hline Respondents who are unsure & 520 & 3.3 \\
\hline Total & 15983 & 100 \\
\hline
\end{tabular}

eThekwini's rural and peri-urban sanitation programme places responsibilities for maintaining UDDTs on households, in an attempt to improve their sense of ownership for the facility. Household members are responsible for the daily cleaning and maintenance of the facility, for ensuring removal of dried faeces from the vault (approximately every 6 to 12 months), as well as using ash or sand. To ensure environmental health regulations are complied with, eThekwini provides each household with equipment to safely dispose of the faecal material (such as shovels, masks and gloves). If household members do not want to participate in vault emptying, they can use the services of local private emptier contractors, trained by and established with help from the municipality. The majority of households $(65.5 \% ; n=10414)$ reported to have emptied the UDDT vault, followed by $28 \%$ ( $n=4460$ ) who have never emptied it (Fig. 3). Of these respondents, approximately $27 \%(n=2803)$ reported that their vaults had been emptied once since installation, $26 \%$ $(25.6 \% ; n=2659)$ reported that it had been emptied twice; $13 \%$ $(n=1343)$ reported that it had been emptied 3 times and $35 \%$ $(n=3613)$ had emptied their vaults more than 3 times (Fig. 2).

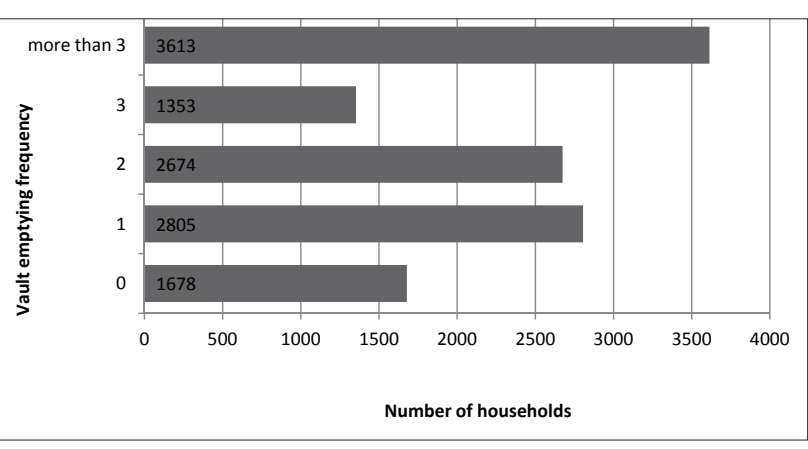

Figure 2

Reported frequency of UDDT emptying

The vast majority of the households $(83.8 \% ; n=8730)$ reported that their vaults were emptied by a family member, whilst only a small proportion $(9.2 \% ; n=959)$ hired an entrepreneur to perform the task.

eThekwini's rural water and sanitation project aimed, among other things, to increase local job opportunities by training and recruiting local skills such as construction and maintenance contractors, establishing local businesses for the supply of building material (bricks, sand, pre-packed dry and concrete mix). A high proportion of households (83\%) felt that the installation of UDDTs did not play any role in increasing employment in the study area (Table 4 ). Only $14 \%$ confirmed that installation of UDDTs had contributed to job creation in the area. This low rate of response from households confirming the economic benefits of the UDDT programme to the local people indicates how the economic benefits of UDDTs are not easily visible to their users.

\begin{tabular}{|l|l|l|}
\hline \multicolumn{3}{|c|}{ TABLE 4 } \\
\hline Increased job creation in UDDTs areas \\
\hline & $\begin{array}{l}\text { Frequency } \\
(\boldsymbol{n})\end{array}$ & $\begin{array}{l}\text { Percentage } \\
(\%)\end{array}$ \\
\hline $\begin{array}{l}\text { Respondents who reported UDDTs } \\
\text { to have increased employment in the } \\
\text { area }\end{array}$ & 2196 & 13.7 \\
\hline $\begin{array}{l}\text { Respondents who believe UDDTs did } \\
\text { not increase employment in the area }\end{array}$ & 13254 & 83.3 \\
\hline $\begin{array}{l}\text { Respondents uncertain about } \\
\text { UDDTs having increased employ- } \\
\text { ment in the area }\end{array}$ & 463 & 2.9 \\
\hline Total & 15913 & 100 \\
\hline
\end{tabular}

Respondents were requested to identify the three most common challenges experienced with UDDTs since their installation. Among these, perception of smell from the toilets ( $71 \%$ of cases and $27 \%$ of responses), lack of privacy from doors not closing properly ( $57 \%$ of cases and $22 \%$ of responses), the use of poor material and workmanship for construction (32\% of cases and $12 \%$ of responses) and the urine pipe not being connected properly ( $31 \%$ of cases and $12 \%$ of responses) were rated as the major challenges faced in the use of UDDTs (Fig. 3).

The results from observations of the UDDTs conducted by enumerators supported households' responses concerning the main challenges of using the toilets (Table 5). Observations reveal that most doors are in place, pedestals are functioning, and vent pipes and back covers are in place. However, fieldworkers report that $84 \%$ of toilets smell and $24 \%$ of the pedestal covers were misplaced and not functioning. 


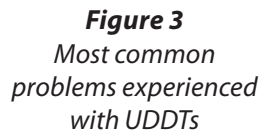

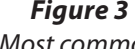

with UDDTs

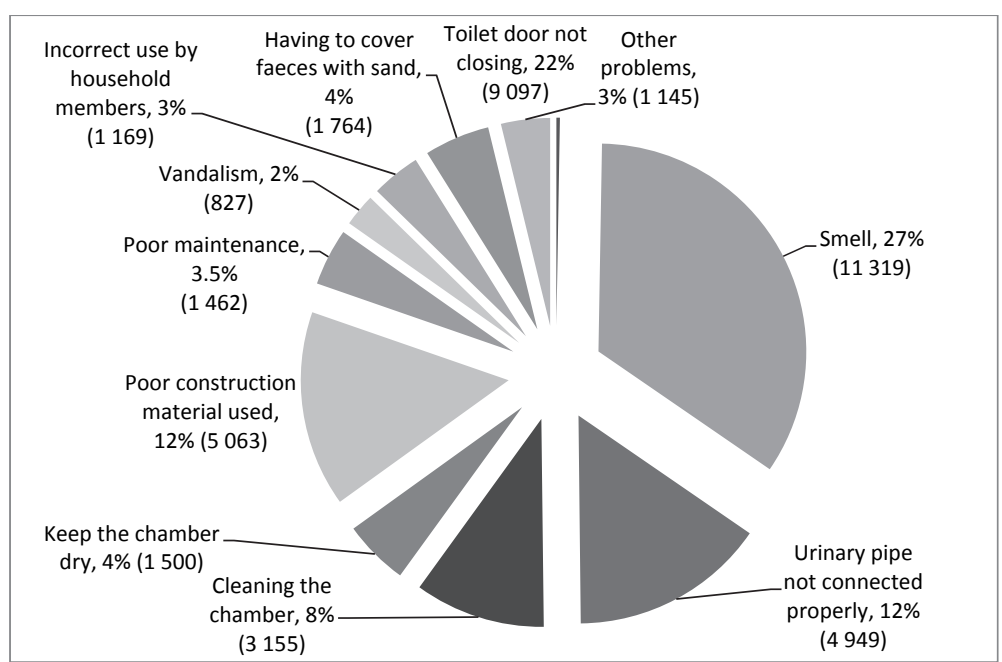

\begin{tabular}{|l|c|c|c|c|}
\hline \multicolumn{5}{|c|}{ TABLE 5 } \\
Observations of the functionality of UDDTs \\
\hline Observation & \multicolumn{2}{|c|}{ Yes } & \multicolumn{2}{c|}{ No } \\
\hline & $\mathbf{n}$ & $\%$ & $\mathbf{N}$ & $\%$ \\
\hline Door in place & 12012 & 75.2 & 3901 & 24.4 \\
\hline Roof in place & 14264 & 89.2 & 1649 & 10.4 \\
\hline Pedestal functioning & 12108 & 75.8 & 3805 & 23.9 \\
\hline Pedestal cover in place & 11987 & 75.0 & 3805 & 23.9 \\
\hline Vent pipe in place & 13245 & 82.9 & 2668 & 16.7 \\
\hline Back cover in place & 13312 & 83.7 & 2601 & 16.3 \\
\hline $\begin{array}{l}\text { Fly screen on the vent } \\
\text { pipe in place }\end{array}$ & 13030 & 81.5 & 2883 & 18.1 \\
\hline Toilet smells & 13407 & 84.3 & 2506 & 15.7 \\
\hline
\end{tabular}

Since the toilet smell was reported to be one of the most critical problems, the causes of smell were further investigated. A Pearson Chi-Square test was conducted to examine whether there is an association between perceived UDDT smell and the poor connection of the urine pipe when the pedestal is moved (Table 6). The results revealed that there is a significant association between the two variables $\left(\chi^{2}=46.114\right.$, df $=1, p<0.001)$.

\begin{tabular}{|l|l|c|c|c|}
\hline \multicolumn{4}{|c|}{ TABLE 6} \\
Pedestal functioning and UDDT-smell cross tabulation \\
\hline \multicolumn{4}{|c|}{} & \multicolumn{2}{|c|}{ Smelling toilet } & \multirow{2}{*}{ No } & yes & Total \\
\cline { 3 - 5 } & No & 3345 & 7619 & 10964 \\
\cline { 2 - 5 } $\begin{array}{l}\text { Urinary pipe not connected } \\
\text { when pedestal is moved }\end{array}$ & Yes & 1249 & 3700 & 4949 \\
\hline Total & 4594 & 11319 & 15913 \\
\hline
\end{tabular}

Household members were asked to report their level of satisfaction with the UDDTs: $23 \%$ of respondents claimed to be satisfied with UDDTs and $7 \%$ 'very satisfied'. However, the majority of respondents (70\%) were not satisfied with UDDTs (Fig, 4).

It was hypothesised that the presence of an alternative sanitation system (such as private pit latrine) may affect the level of satisfaction with UDDTs (Table 7). Results from a Pearson Chi Square test show the presence of an association between low satisfaction with UDDT and ownership of a pit latrine $\left(\chi^{2}=9.328 ; \mathrm{df}=2 ; p=<0.05\right)$.

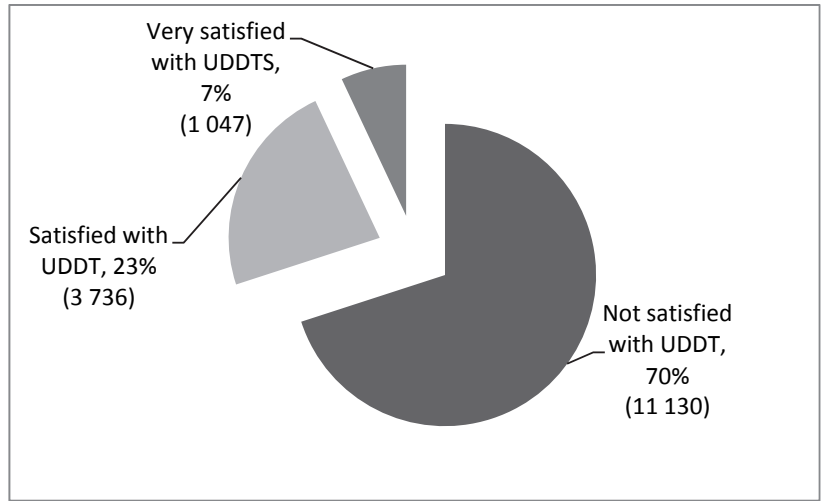

Figure 4

Reported satisfaction with UDDTs

TABLE 7

Pit latrine presence and level of satisfaction with UDDTs: Cross tabulation

\begin{tabular}{|l|c|c|c|c|c|}
\hline \multicolumn{2}{|c|}{} & \multicolumn{3}{|c|}{$\begin{array}{c}\text { Level of satisfaction with UD } \\
\text { toilets }\end{array}$} & \multirow{2}{*}{ Total } \\
\cline { 3 - 5 } \multicolumn{2}{|c|}{} & $\begin{array}{c}\text { Very } \\
\text { satisfied }\end{array}$ & Satisfied & $\begin{array}{c}\text { Not } \\
\text { satisfied }\end{array}$ & \\
\hline $\begin{array}{l}\text { Have a pit } \\
\text { latrine }\end{array}$ & Yes & 116 & 517 & 1610 & 2243 \\
\cline { 2 - 5 } & No & 931 & 3219 & 9520 & 13670 \\
\hline \multicolumn{2}{l|l}{ Total } & 1047 & 3736 & 11130 & 15913 \\
\hline
\end{tabular}

\section{DISCUSSION}

This large cross-sectional study provides an overview of the conditions of UDDTs in eThekwini Municipality after almost a decade since the installation of the toilets. Among the most important post-implementation issues emerging from the survey was the high proportion of sampled population reporting low satisfaction with UDDTs (70\%). We compared results from this survey with a monitoring study on 1100 respondents conducted between 2003 and 2004 in a few of the same areas of eThekwini Municipality (HSRC, 2004). Although our crosssectional study did not focus on the same subjects as the 2004 study, the comparison shows that the total level of satisfaction has decreased since $2003 / 04$. Whilst in $2004,78.4 \%$ of respondents reported to be satisfied with the UDDTs implemented 
(51.3\% strongly agreed and $27.1 \%$ agreed) the level of satisfaction in the cross-sectional study is below $30 \%$. These results are also corroborated by previous research on satisfaction with UDDTs in South Africa (Matsebe and Duncker, 2005), where findings show that user satisfaction with UDDTs has decreased with time in the KwaZulu-Natal and Northern Cape provinces. As illustrated in previous contributions (Drangert, 2004), expectations play a fundamental role in shaping people's attitudes towards sanitation systems. The end of Apartheid, brought several expectations for the provision of basic services (such as water and sanitation) by Government to the previously-neglected Black and mixed communities.

Similarly, the challenges reported by UDDT users in eThekwini Municipality (poor construction and smell) are comparable to those reported by users in other areas of the country (Holden et al., 2004; Duncker et al., 2007). In the Northern Cape Province, for instance, poor construction materials and techniques resulted in the urine pipes being too narrow, leading to blockages and subsequent smell problems. In eThekwini Metro, toilets' smell was also reported as a constraint to their use. From the analysis of the data collected and reported in Table 6 , an association was identified between users' perceptions of smell and the fact that the pedestal was not in place. This may be linked to poor workmanship and inappropriate use of the system, and further technical inspections are recommended. A comparison with similar studies conducted in developing countries enabled us to identify a series of common hurdles to acceptance and sustained use of UDDTs and EcoSan. These are summarised in Table 8.

\begin{tabular}{|l|l|l|}
\hline \multicolumn{3}{|c|}{ TABLE 8 } \\
\hline Hurdles & References & Country \\
\hline \multirow{3}{*}{ Smell/odour } & $\begin{array}{l}\text { Current study; } \\
\text { Holden et al. (2004) }\end{array}$ & South Africa \\
\cline { 2 - 3 } & Drangert (2004) & Ethiopia \\
\hline Maintenance issue & Holden et al. (2004) & South Africa \\
\hline $\begin{array}{l}\text { Distance from } \\
\text { Household }\end{array}$ & Current study & South Africa \\
\hline \multirow{2}{*}{ Handling excreta } & Holden et al.(2004) & South Africa \\
\cline { 2 - 3 } & Drangert (2004) & Ethiopia \\
\hline Comfort & Holden et al.(2004) & South Africa \\
\hline Privacy, security & Holden et al. (2004) & South Africa \\
\hline \multirow{3}{*}{ Capital costs } & Holden et al. (2004) & South Africa \\
\cline { 2 - 3 } & Nuwagaba (2011) & Uganda \\
\cline { 2 - 3 } & Lungu et al. (2008) & Malawi \\
\hline
\end{tabular}

Some adaptive processes which emerged from this study are highlighted for further investigation. As reported in Table 7 , an association was identified between poor satisfaction with UDDTs and presence of a private pit latrine in the household's yard. This study focused merely on the UDDTs system without considering aspects such as its location in relation to the users' dwelling. As highlighted by a growing body of evidence (Drangert et al., 2004; Roma et al., 2010), perceptions of sanitation systems are often related to convenience and privacy, which are associated with having a toilet within close proximity of the dwelling. This may explain the reason why those respondents who have a pit toilet reported low satisfaction with UDDTs, as pits are conveniently positioned close to the dwelling. Thus, as suggested for other studies conducted on UDDTs in Mexico (Drangert et al., 2004), there are reasons to explore the option of having UDDTs indoors or immediately adjacent to the dwelling. A further hypothesised explanation for low satisfaction with UDDTs is that users do not perceive any difference between a pit latrine and EcoSan and do not recognise their added value. In South Africa, in fact, any form of sanitation system that does not involve flushing is still seen as a sub-standard type compared to the flush toilets to which the poor population aspire (Duncker, 2006; Duncker et al., 2007). A mechanism to increase adaptation would be to link the sanitation facilities to the economic revenue stemming from reuse and recycling of human waste, so that appropriate use and maintenance are increased. In Uganda, Tumwebaze et al. (2011) showed that users' awareness of the economic value of EcoSan is associated with toilet uptake and coverage. The key to improve acceptance is for users to understand the importance and potential of waste as a useful resource. To do so, educational activities and participatory approaches should be conducted based on an in-depth understanding of people's learning culture. In Tanzania, Shayo (2004) showed that the use of PHAST (participatory hygiene and sanitation transformation) methodology at all stages of project implementation in the piloting of EcoSan toilets in Dar Es Salaam has resulted in high acceptance of the toilets.

\section{CONCLUSIONS}

This contribution represents one of the largest cross-sectional studies exploring user acceptance of dry sanitation, and as such makes a valuable contribution to scientific understanding of the effectiveness of this relatively new technology. Dry sanitation is spreading rapidly as a technological solution in developing countries to address the capital costs, infrastructural issues and environmental considerations linked to sewer systems. Through the analysis of user feedback this study has highlighted critical post-implementation issues that have emerged with UDDTs in eThekwini Municipality, a decade after their installation. Addressing user satisfaction is a fundamental component in implementing the next stage of 'drop and reuse' sanitation. In this respect, educational activities would play a fundamental role in help overcoming negative perceptions and societal barriers towards excreta reuse. Furthermore, constant monitoring of adoption processes should be further investigated in routine evaluations to identify causation and thus intervene to increase sustainability of the systems.

\section{ACKNOWLEDGMENTS}

The authors are grateful to the two anonymous reviewers whose comments made the final version of this manuscript possible. This study was made possible thanks to the support of eThekwini Municipality. Particularly, the authors would like to thank Neil Macleod, Teddy Gounden, Lucky Sibyia, EWS environmental health officers as well as local communities in the rural areas for their support and knowledge shared.

\section{REFERENCES}

AUSTIN LM and VAN VUUREN SJ (2001) Sanitation, public health and the environment: looking beyond the current technologies. J. S. Afr. Inst. Civ. Eng. 43 (1) 29-33.

CHAPLIN S (2004) Cities, sewers and poverty: India's politics of sanitation. Environ. Urban. 11 (1) 145-158.

DALY HE and FARLEY J (2004) Ecological Economics. Principles and Applications. Island Press, Washington. 
DRANGERT JO (1998) Fighting the urine blindness to provide more sanitation options. Water SA 24 (2) 157-164.

DRANGERT JO (2004) Norms and Attitudes Towards EcoSan and Other Sanitation Systems. EcoSanRes Publication Series, Stockholm Environment Institute, Sweden.

DUNCKER LC, MATSEBE GN and MOILWA N (2007) The Social/ Cultural Acceptability of using Human Excreta (Faeces and Urine) for Food Production in Rural Settlements in South Africa. WRC Report No. TT 310/07. Water Research Commission, Pretoria.

DWAF (DEPARTMENT OF WATER AFFAIRS AND FORESTRY, SOUTH AFRICA) (2001) White Paper on Basic Household Sanitation. Department of Water Affairs and Forestry, South Africa. URL: http://www.dwaf.gov.za/dir ws/waterpolicy/vdFileLoad/file.asp?ID=78 (Accessed 23 December 2012).

DWAF (DEPARTMENT OF WATER AFFAIRS AND FORESTRY, SOUTH AFRICA) (2003) Strategic Framework for Water Services: Water is Life, Sanitation is Dignity. Department of Water Affairs and Forestry, Cape Town, South Africa. URL: http://www.wisa.org. za/downloads/Strategic framwork for water services2003.pdf (Accessed 23 December 2012).

EALES K (2008) Rethinking sanitation improvement for poor households in urban South Africa. IRC Symposium: Sanitation of the Urban Poor Partnership and Governance, 19-21 November 2008, Delft, The Netherlands. URL: http://www.irc.nl/page/46156 (Accessed March 2012).

ESREY SA (2000) Towards a recycling society. Ecological sanitation - closing the loop to food security. Paper presented at the GIZ Ecological Sanitation Symposium, October 2000, Bonn, Germany.

EWS (eTHEKWINI WATER AND SANITATION) (2010) The introduction of volume based sewage disposal charges from $1^{\text {st }}$ July 2010. eThekwini Water and Sanitation, Durban, South Africa

GOUNDEN T, PFAFF B, MACLEOD N and BUCKLEY CA (2006) Provision of free sustainable basic sanitation: the Durban experience. Proc. $32^{\text {nd }}$ WEDC International Conference on Sustainable Development of Water Resources, Water Supply and Environmental Sanitation, November 2006, Colombo, Sri Lanka. URL: www2. gtz.de/Dokumente/oe44/ecosan/en-durban-experience-2006.pdf (Accessed 21 November 2011).

HOLDEN R, TERREBLANCHE R and MULLER M (2004) Factors which have influenced the acceptance of EcoSan in South Africa and development of a marketing strategy. In: Werner C, Avendaño V, Demsat S, Eicher I, Hernandez L, Jung C, Kraus S, Lacayo I, Neupane K, Rabiega A and Wafler M (eds.) Ecosan - Closing the Loop. Proceedings of the 2nd International Symposium on Ecological Sanitation, 07-11 April 2003, Lübeck, Germany. 167-174.

HSRC (HUMAN SCIENCES RESEARCH COUNCIL) (2004) Assessment of the effectiveness of the education programme for households receiving sanitation and water. HSRC, Durban.

LANGERGRABER G and MUELLEGGER E (2005) Ecological sanitation - a way to solve global sanitation problems? Environ. Int. 31 $433-444$.

LUNGU K, MORSE TD and GRIMASON AM (2008) Ecological sanitation - implementation opportunities and challenges in Chikwawa, Malawi. Environ. Health Int. 10 (2) 1-7.
MATSEBE G and DUNCKER L (2005) Urine diversion in South Africa: is this a solution? Paper presented at EcoSan Conference, May 2005, Durban, South Africa.

MUDZANANI L, RATSAKA-MATHOKOA M, MAHLASELA L, NETSHIDZIVHANI P and MUGERO C (2003) Cholera. In: Ijumba P, Day C and Ntuli A (eds.) South Africa Health Review 2003/2004. Health System Trust, Durban. URL: http://www.hst. org.za/publications/south-african-health-review-200304 (Accessed 1 July 2011).

PENNER B (2010) Flush with inequality: sanitation in South Africa. URL: http://places.designobserver.com/entry.html?entry=21619 (Accessed 3 February 2011).

ROMA E, HOLZWARTH S and BUCKLEY CA (2011) Large-scale periurban and rural sanitation with UDDTs in eThekwini Municipality (Durban), South Africa. SuSanA Case Study. URL: http://www. susana.org/docs ccbk/susana download/2-791-en-susana-cssouth-africa-ethekwini-durban-uddts-2010.pdf (Accessed 20 March 2012).

SHAYO AJ (2004) Acceptance of Ecosan concepts in Tanzania - a case study of piloting ecological sanitation, Majumbasita, Dar Es Salaam. In: Werner C, Avendaño V, Demsat S, Eicher I, Hernandez L, Jung C, Kraus S, Lacayo I, Neupane K, Rabiega A and Wafler M (eds.) Ecosan - Closing the Loop. Proceedings of the 2nd International Symposium on Ecological Sanitation, 07-11 April 2003, Lübeck, Germany.

TRÖNNBERG L, HAWKSWORTH D, HANSEN A, ARCHER C and STRENSTRÖM TA (2010) Household-based prevalence of helminths and parasitic protozoa in rural KwaZulu-Natal, South Africa, assessed from faecal vault sampling. Trans. R. Soc. Trop. Med. Hyg. 104 642-652.

TUMWEBAZE IK, ORAC CG, NAKAYAGA JK, KARAMAGI C, LUETHI C and NIWAGABA C (2011) Ecological sanitation coverage and factors affecting its uptake in Kabale municipality, western Uganda. Int. J. Environ. Health Res. 21 (4) 294-305.

UNEP (UNITED NATIONS ENVIRONMENT PROGRAMME (2008) Vital Water Graphics. An Overview of the State of The World's Fresh and Marine Waters ( $2^{\text {nd }}$ edn.) UNEP, Nairobi, Kenya. URL: http://www.unep.org/dewa/vitalwater/article83.html (Accessed 21 December 2012).

UN-WATER (2006) Coping with water scarcity. A strategic issue and priority for system wide action. Un-Water Thematic Issue, August 2006. URL: ftp://ftp.fao.org/agl/aglw/docs/waterscarcity.pdf (Accessed 12 March 2012).

WHO (2006) Guidelines for the Safe Use of Wastewater, Excreta and Greywater. Vol. IV Excreta and Greywater Use in Agriculture. WHO, Switzerland. URL: http://www.who.int/water sanitation health/wastewater/gsuww/en/index.html (Accessed 12 March 2012).

WIN-SA (2006) eThekwini's water and sanitation programme: WIN-SA lessons series. Water Information Network South Africa. URL: http://www.susana.org/lang-en/library?view=ccbktypeitem\& type $=2 \& i d=1170$ (Accessed 12 March 2012). 
http://dx.doi.org/10.4314/wsa.v39i2.15 Available on website http://www.wrc.org.za

ISSN 0378-4738 (Print) = Water SA Vol. 39 No. 2 April 2013 ISSN 1816-7950 (On-line) = Water SA Vol. 39 No. 2 April 2013 